\title{
Health and social care, together at last?
}

\author{
Fiona Godlee editor in chief
}

The BMJ

How much of the rising pressure on the NHS could be relieved by proper funding and organisation of public health and social care? We are far from achieving either: cuts to public health are making people ill; failures of social care are keeping people in hospital when they could be at home.

Pressure on the NHS is nothing new. "Disseminating hyporesourcitis" was The BMJ's diagnosis back in the Thatcher 1980s (www.bmj.com/content/bmj/292/6529/1212.full.pdf).

But the looming crisis is now big enough to be seen if not from space then at least from the United States (https://www.nytimes. com/2018/01/16/opinion/nhs-britain-crisis.html). On BMJ Opinion (blogs.bmj.com/bmj) this week the independently minded politician Sarah Wollaston calls for a whole system approach, encompassing public health and social care. These systems cannot be considered in isolation, she says.

So what difference can we expect now that health and social care are both the responsibility of a newly dubbed secretary of state for health and social care (doi:10.1136/bmj.k208)? Not much, says David Oliver (doi:10.1136/bmj.k136). For one thing, the group advising Jeremy Hunt on social care includes people long associated with the current muddle. "The problems facing the social care system are just the kind of thorny issue we elect governments to solve," he says. But he's not holding his breath.
Jon Glasby is similarly cautious (doi:10.1136/bmj.k201). Hunt's new title feels like progress, he says. But our health and social care services are fundamentally different and not designed for integration: one is national, universal, and largely free at the point of delivery; the other is local, targeted, and means tested. A single department changes nothing, Glasby says.

Wollaston now wants to see all options for funding and integration clearly set out for the public to consider. These should include ways of achieving intergenerational fairness, she says, perhaps through a hypothecated tax borne by wealthier over 40s. Hypothecation is gaining popularity. It was, however, roundly dismissed by John Appleby (doi:10.1136/bmj.j471). Also dismissed, by Nigel Crisp, was the idea of a royal commission (doi:10.1136/bmj.j1621).

But while Brexit continues to steal the political oxygen (doi:10. 1136/bmj.k189), it's hard to see what else will lift this precious public service out of the mire of short term party politics and give it the long term visionary thinking it urgently needs.

\section{Follow Fiona Godlee on Twitter @fgodlee}

Published by the BMJ Publishing Group Limited. For permission to use (where not already granted under a licence) please go to http://group.bmj.com/group/rights-licensing/ permissions 